Systematic Review

\title{
Systematic Review of Intrathecal Infusion Systems for Long-Term Management of Chronic Non-Cancer Pain
}

Vikram B. Patel, MD¹, Laxmaiah Manchikanti, MD², Vijay Singh, MD³, David M. Schultz, MD, Salim M. Hayek, MD, PhD ${ }^{5}$, and Howard S. Smith, MD

From: ${ }^{1} \mathrm{ACMI}$ Pain Care Algonquin, IL; 2Pain Management Center of Paducah,

Paducah, KY; ${ }^{3}$ Pain Diagnostics

Associates Niagara, WI; ${ }^{4}$ Medical Advanced Pain Specialists, Minneapolis, MN; 5 University Hospitals of Cleveland And Outcomes Research Consortium,

Cleveland, $\mathrm{OH}$; and ${ }^{6} \mathrm{Albany}$ Medical College, Albany, NY

Dr. Patel is Medical Director of ACMI Pain Care, Algonquin, IL. Dr. Manchikanti is Medical Director of the Pain Management

Center of Paducah, Paducah, KY, and Associate Clinical Professor of Anesthesiology and Perioperative Medicine, University of Louisville, Louisville, KY. Dr. Singh is Medical Director of Pain Diagnostics Associates, Niagara, WI. Dr. Schultz is the Medical Director of Medical Advanced Pain Specialists, Minneapolis, MN. Dr. Hayek is Chief of the Division of Pain Medicine, Department of Anesthesiology, University Hospitals of Cleveland, Cleveland, $\mathrm{OH}$; and a member of the Outcomes Research Consortium,

Cleveland, OH. Dr. Smith is Associate Professor and Academic Director of Pain Management for Albany Medical College Department of Anesthesiology, Albany, NY.

Address correspondence: Vikram B. Patel, MD FIPP President \& Medical Director ACMI Pain Care, LLC 1479 Commerce Drive Algonquin, IL 60102

E-mail: vikpatel1@yahoo.com

Disclaimer: Dr. Schultz receives funding from Medtronic. Conflict of interest: None.

Manuscript received: $11 / 28 / 2008$ Revised manuscript received: 01/18/2009

Accepted for publication: 01/23/2009

Free full manuscript: www.painphysicianjournal.com
Background: Disability, societal, and health impact of chronic intractable pain secondary to various failed therapies is a major issue. As advanced therapy, implantable therapies, which include intrathecal devices and spinal cord stimulation systems, are frequently used in managing chronic intractable pain. Thus, continuous infusion of intrathecal medication is one of the methods used for the control of chronic, refractory, cancer, and non-cancer pain. However, despite the high costs of chronic non-cancer pain, it has been claimed that there is a lack of evidence for intrathecal infusion systems and the cost effectiveness of these systems has been questioned in improving pain and function.

Study Design: A systematic review of intrathecal infusion devices for chronic non-cancer pain

Objective: To determine the efficacy, utilization, safety, and complications associated with the use of intrathecal infusion devices for long-term management of chronic non-cancer pain.

Methods: Literature search was performed through EMBASE, Medline, Cochrane databases, and systematic reviews identified from 1966 to December 2008. Studies were then reviewed and assessed using the Agency for Healthcare Research and Quality (AHRQ) criteria for observational studies and the Cochrane Musculoskeletal Review Group criteria for randomized trials.

The level of evidence was determined using 5 levels of evidence, ranging from Level I to III with 3 subcategories in Level II, based on the quality of evidence developed by the U.S. Preventive Services Task Force (USPSTF)

Outcome Measures: The primary outcome measure was pain relief (short-term relief $\leq$ one-year and long-term > one-year). Secondary outcome measures of improvement in functional status, psychological status, return to work, and reduction in opioid intake were also utilized.

Results: The level of evidence for intrathecal infusion systems indicated either Level II-3 or Level III (limited) based on U.S. Preventive Services Task Force (USPSTF) criteria.

Limitations: The limitations of this study include the paucity of literature, lack of quality evidence, and lack of randomized trials.

Conclusion: This systematic review illustrates Level II-3 or Level III (limited) evidence for intrathecal infusion systems for long-term relief in chronic non-cancer pain.

Key words: Intrathecal infusion, intraspinal infusion, programmable infusion systems, spinal infusion, intra-spinal infusion devices, baclofen infusion, intrathecal opiates

Pain Physician 2009; 12:345-360 
S pinal pain is associated with significant economic, societal, and health impact (1-16). Estimates and patterns of direct health care expenditures among individuals with back pain in the United States reached $\$ 90.7$ billion for the year 1998 (3). In the United States, it was estimated that the cost of treatment in the first year after failed back surgery for pain was approximately $\$ 18,883$ in 1997 (4). In addition to this, annual heath care costs incurred by chronic pain patients, excluding cost for surgical procedures, may range from as low as $\$ 500.00$ to as high as $\$ 35,400(4,5)$. Deyo et al $(9)$ showed that the prevalence of chronic back pain and its impact has spawned a rapidly expanding range of tests and treatments, with wide usage for indications that are not well validated, leading to uncertainty about efficacy and safety, increasing complication rates, and marketing abuses. They also showed that the limited studies available suggest that these increases have not been accompanied by population-level improvements in patient outcomes or disability rates. Asche et al (8) reviewed low back pain studies with economic implications in order to determine whether the societal costs attributed to lower back pain have changed since 2001, a time during which low back pain treatment guidelines were updated. They concluded that cost estimates for the management of low back pain were high, consistent with the results of the review of low back pain economic studies published prior to 2001. Newer, more costly agents will increase drug costs as a portion of total cost, particularly if not used in accordance with treatment guidelines.

Stewart et al (15) in an evaluation of low productive time (LPT) and cost due to common pain conditions in the U.S. work force concluded that pain is an inordinately common and disabling condition in the U.S. work force, with most of the pain-related LPT occurring while employees are at work resulting in reduced performance. Martin et al (16) in a review of expenditures and health status among adults with back and neck problems in the United States concluded that self-reported back and neck problems accounted for a large portion of health care expenditures, with spine-related expenditures increasing substantially from 1997 to 2005, without evidence of corresponding improvements in self-assessed health status. Further, studies have shown the rising prevalence of chronic low back pain (2).

Failed back surgery syndrome is a common problem in the modern world, specifically in the United
States (17-21). Recent literature about the utilization of surgical interventions in the United States shows that in the year 2002, more than one million spinal procedures were performed with 400,000 cases being instrumented (22-26). Management of failed back surgery syndrome with multiple modalities, including interventional techniques, results in moderate improvements, yet leaves a proportion of patients in intractable pain (1,27-38).

As an advanced stage intervention, implantable therapies, which include spinal cord stimulation systems and implantable intrathecal devices, are frequently used in managing chronic intractable pain. Thus, continuous infusion of intrathecal medication is one of the methods used for control of chronic, refractory, malignant, and non-cancer related pain. However, along with costs of inpatient surgery, expenses for implantable therapy have increased substantially in the entire population and specifically in the Medicare population (39-43). Thus, given the high cost of intrathecal implantables and lack of demonstrated effectiveness, there has been substantial controversy with the usage of intrathecal infusion systems (44-48).

Bennett et al (49) concluded that clinical efficiency in large-scale randomized controlled trials (RCTs) utilizing intrathecal delivery of most compounds has not been demonstrated and variations between study designs make useful comparisons of existing studies difficult. Walker et al (50) concluded that the evidence for the safety and effectiveness of combination spinal analgesic therapies is moderate in acute pain, whereas, they found limited or no evidence to support the combination analgesics in chronic pain. Turner et al (51), in a systemic review of effectiveness and complications of programable intrathecal opioid delivery systems for chronic non-cancer pain, included 6 studies in the evidence synthesis and found improvement in pain among patients who received a permanent intrathecal drug delivery system (5257). Boswell et al (1) concluded that there is moderate evidence for long-term management of chronic pain with intrathecal infusion systems at one year or longer follow-up. Manchikanti et al (48) in a reassessment of an evidence synthesis by the American College of Occupational and Environmental Medicine (ACOEM) guidelines also found moderate evidence for long-term management of chronic non-cancer pain with intrathecal infusion systems. In addition, a cost effectiveness evaluation showed intrathecal morphine delivery resulting in low cumulative 60-month 
costs of $\$ 16,579$ per year, $\$ 1,382$ per month versus medical management of $\$ 17,037$ per year, $\$ 1,420$ per month (58). Cost effectiveness was also shown with a total cost of intrathecal morphine over 60 months of $\$ 82,893$, an average of $\$ 1,382$ per month (5). However, due to all the randomized trials evaluating only short-term relief, the evidence has been shown to be limited in other guidelines (44-48).

This systematic review is undertaken to provide a comprehensive and systematic review of the available literature on intrathecal implantables in managing chronic non-cancer pain.

\section{Methods}

\section{Literature Search}

A literature search was conducted from 1966 through December 2008 using multiple sources including Medline and EMBASE databases, the Cochrane library, systematic and narrative reviews, NIH Clinical Trials Registry, and bibliographic references. Only English language articles were screened.

The search terminology included implantable infusion (drug delivery systems), intrathecal, infusion of morphine, bupivacaine, clonidine, hydromorphone, baclofen, ziconotide, chronic pain, chronic low back pain and chronic non-cancer pain, failed back surgery syndrome, post-surgery syndrome, and arachnoiditis.

\section{Selection Criteria}

The studies included in this review had to meet the following criteria:

- Studies should clearly show the use of intrathecal infusion device/system (programmable or fixed infusion rate) implanted for non-cancer pain for long-term use.

- Studies must have a specific indication for intrathecal infusion and the drug injected.

- A minimum of 12 months of follow-up was available.

- Clear documentation of patient outcomes and complications should have been provided.

- Number of patients evaluated must be at least 25.

Exclusion criteria were as follows:

- Lack of clear documentation of infusion systems or mixed delivery methods.

- Externalized infusion systems for short-term use.

- Studies for non-cancer pain with less than 12 months follow-up.
- Lack of clear documentation of the indications and patient population being studied.

\section{Types of Outcome Measures}

Primary Outcome Measure: $\geq 50 \%$ pain relief

Secondary Outcome(s): Improvement of function, reduction in the amount of oral medication, decrease in side effects from systemic drugs, and improvement in quality of life (QOL).

Pain and symptom improvement is evaluated on both short-term (12 months or less) and long-term (more than 12 months) basis.

\section{Review Methods}

\section{Review Criteria}

Each study was evaluated by 2 physicians for the stated criteria and any disagreements were resolved by a third physician.

If there was a conflict of interest with the reviewed manuscripts with authorship or any other type of conflict, the involved authors did not review the manuscripts for quality assessment, clinical relevance, evidence synthesis, or grading of evidence.

\section{Methodological Quality Assessment}

The quality of each individual article used in this analysis was assessed by modified Cochrane review criteria with weighted scores (59) for randomized trials and the Agency for Healthcare Research and Quality (AHRQ) quality criteria for assessment of observational studies (60) with consensus-based weighted scoring developed by the guidelines committee of the American Society of Interventional Pain Physicians (ASIPP) which has been utilized in several other evaluations $(28,36,38,48,61-68)$.

Only the studies scoring at least 50 of 100 on weighted scoring criteria were utilized for analysis.

\section{Data Extraction}

A standardized form was used to extract the relevant data on the methods used, participants, interventions, outcome measures used and timing of outcome measurement, reported side effects, and the main results.

\section{Analysis of Evidence:}

Qualitative analysis was conducted using 5 levels of evidence as described by AHRQ, ranging from Level I to Level III with 3 subcategories in Level II, as illustrated in Table 1 (69). 
Table 1. Quality of evidence developed by USPSTF.

\begin{tabular}{|c|l||}
\hline I: & Evidence obtained from at least one properly randomized controlled trial \\
\hline II-1: & Evidence obtained from well-designed controlled trials without randomization \\
\hline II-2: & $\begin{array}{l}\text { Evidence obtained from well-designed cohort or case-control analytic studies, preferably from more than one } \\
\text { center or research group }\end{array}$ \\
\hline II-3: & $\begin{array}{l}\text { Evidence obtained from multiple time series with or without the intervention. Dramatic results in uncontrolled } \\
\text { experiments (such as the results of the introduction of penicillin treatment in the 1940s) could also be regarded } \\
\text { as this type of evidence }\end{array}$ \\
\hline III: & $\begin{array}{l}\text { Opinions of respected authorities, based on clinical experience descriptive studies and case reports or reports of } \\
\text { expert committees }\end{array}$ \\
\hline \hline
\end{tabular}

Adapted from the U.S. Preventive Services Task Force (USPSTF) (69).

Table 2. Grading recommendations.

\begin{tabular}{|c|c|c|c|}
\hline $\begin{array}{c}\text { Grade of Recommendation/ } \\
\text { Description }\end{array}$ & $\begin{array}{c}\text { Benefit vs Risk and } \\
\text { Burdens }\end{array}$ & $\begin{array}{l}\text { Methodological Quality of } \\
\text { Supporting Evidence }\end{array}$ & Implications \\
\hline $\begin{array}{l}\text { 1A/strong recommendation, high- } \\
\text { quality evidence }\end{array}$ & $\begin{array}{l}\text { Benefits clearly outweigh } \\
\text { risk and burdens, or vice } \\
\text { versa }\end{array}$ & $\begin{array}{l}\text { RCTs without important limitations } \\
\text { or overwhelming evidence from } \\
\text { observational studies }\end{array}$ & $\begin{array}{l}\text { Strong recommendation, } \\
\text { can apply to most patients in } \\
\text { most circumstances without } \\
\text { reservation }\end{array}$ \\
\hline $\begin{array}{l}1 \mathrm{~B} / \text { strong recommendation, moder- } \\
\text { ate quality evidence }\end{array}$ & $\begin{array}{l}\text { Benefits clearly outweigh } \\
\text { risk and burdens, or vice } \\
\text { versa }\end{array}$ & $\begin{array}{l}\text { RCTs with important limitations } \\
\text { (inconsistent results, methodologi- } \\
\text { cal flaws, indirect, or imprecise) or } \\
\text { exceptionally strong evidence from } \\
\text { observational studies }\end{array}$ & $\begin{array}{l}\text { Strong recommendation, } \\
\text { can apply to most patients in } \\
\text { most circumstances without } \\
\text { reservation }\end{array}$ \\
\hline $\begin{array}{l}\text { 1C/strong recommendation, low- } \\
\text { quality or very low-quality evidence }\end{array}$ & $\begin{array}{l}\text { Benefits clearly outweigh } \\
\text { risk and burdens, or vice } \\
\text { versa }\end{array}$ & Observational studies or case series & $\begin{array}{l}\text { Strong recommendation but } \\
\text { may change when higher qual- } \\
\text { ity evidence becomes available }\end{array}$ \\
\hline $\begin{array}{l}\text { 2A/weak recommendation, high- } \\
\text { quality evidence }\end{array}$ & $\begin{array}{l}\text { Benefits closely balanced } \\
\text { with risks and burden }\end{array}$ & $\begin{array}{l}\text { RCTs without important limitations } \\
\text { or overwhelming evidence from } \\
\text { observational studies }\end{array}$ & $\begin{array}{l}\text { Weak recommendation, best } \\
\text { action may differ depending } \\
\text { on circumstances or patients' } \\
\text { or societal values }\end{array}$ \\
\hline $\begin{array}{l}2 \mathrm{~B} / \text { weak recommendation, moderate- } \\
\text { quality evidence }\end{array}$ & $\begin{array}{l}\text { Benefits closely balanced } \\
\text { with risks and burden }\end{array}$ & $\begin{array}{l}\text { RCTs with important limitations } \\
\text { (inconsistent results, methodologi- } \\
\text { cal flaws, indirect, or imprecise) or } \\
\text { exceptionally strong evidence from } \\
\text { observational studies }\end{array}$ & $\begin{array}{l}\text { Weak recommendation, best } \\
\text { action may differ depending } \\
\text { on circumstances or patients' } \\
\text { or societal values }\end{array}$ \\
\hline $\begin{array}{l}2 \mathrm{C} / \text { weak recommendation, low-qual- } \\
\text { ity or very low-quality evidence }\end{array}$ & $\begin{array}{l}\text { Uncertainty in the estimates } \\
\text { of benefits, risks, and burden; } \\
\text { benefits, risk, and burden } \\
\text { may be closely balanced }\end{array}$ & Observational studies or case series & $\begin{array}{l}\text { Very weak recommendations; } \\
\text { other alternatives may be } \\
\text { equally reasonable }\end{array}$ \\
\hline
\end{tabular}

Adapted from Guyatt $\mathrm{G}$ et al. Grading strength of recommendations and quality of evidence in clinical guidelines. Report from an American College of Chest Physicians task force. Chest 2006; 129:174-181 (70).

\section{Recommendations}

Grading recommendations were based on Guyatt et al's criteria as illustrated in Table 2 (70).

\section{Results}

Figure 1 illustrates the results of the literature search for intrathecal infusion systems. 


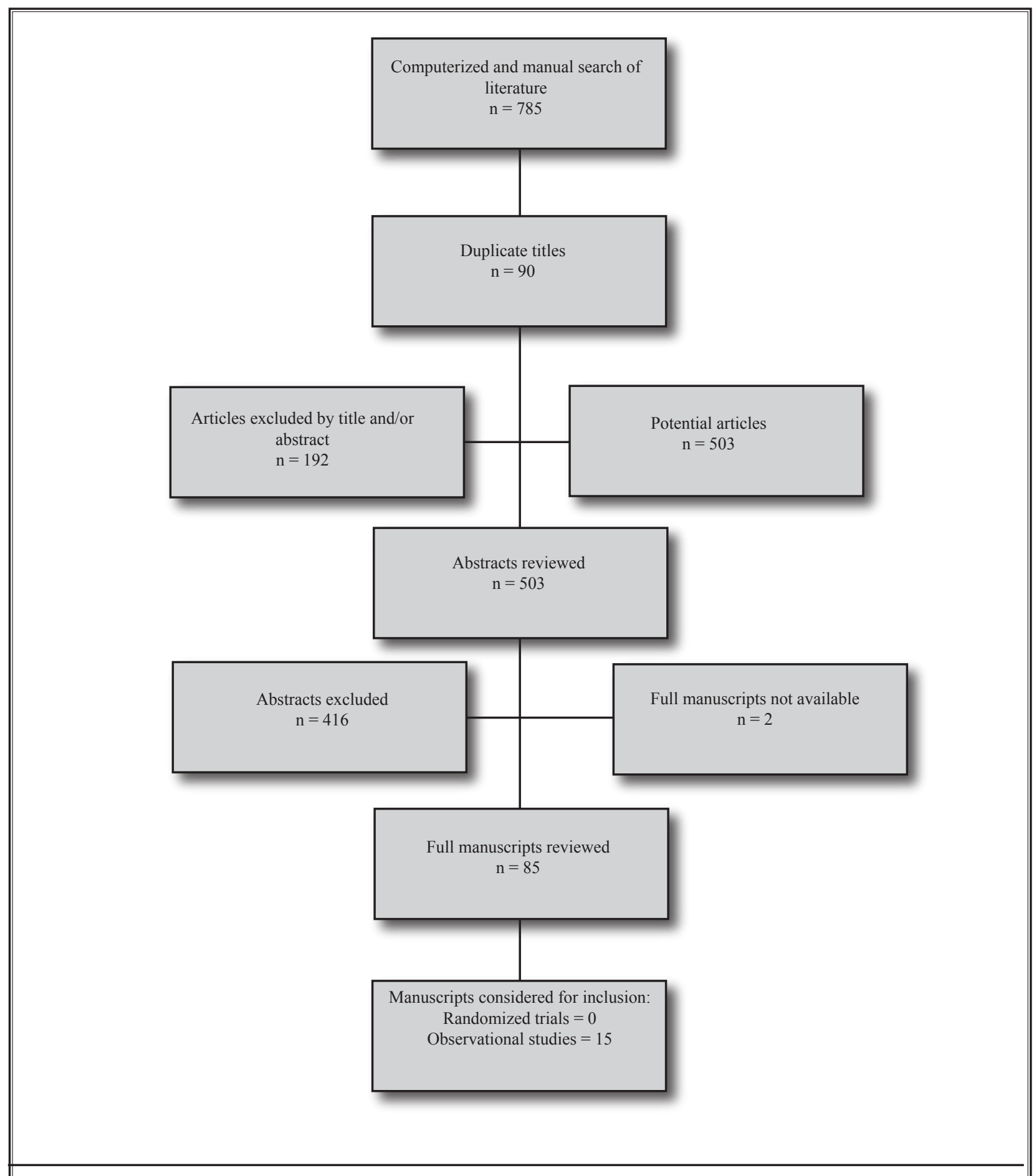

Fig. 1. The flow diagram illustrating published literature evaluating intrathecal infusion systems. 
After a comprehensive search and evaluation of the available studies for intrathecal infusion devices as well as drugs infused for non-cancer pain, qualified studies were tabulated. Overall, 15 of the intrathecal infusion for non-cancer pain were identified (52-57,71-79).

\section{Methodologic Quality Assessment}

Nine studies $(52,54,56,57,71-75)$ met inclusion criteria for methodologic quality assessment with at least 12 months of follow-up. However, there were no randomized trials. Of the 9 studies, 4 studies were excluded because they included less than 25 patients. Of the studies not meeting inclusion criteria, one study included 23 patients (55), the second study included 16 patients (53), the third study was excluded for sample size of 24 (75), and another study included 16 patients (77).

Table 3 illustrates the methodologic quality assessment of 5 observational studies $(54,71-74)$ evaluating non-cancer pain. The quality assessment scores of the included studies $(54,71-74)$ ranged from 49 to 60 with only 4 (71-74) meeting inclusion criteria for evidence synthesis (score $\geq 50$ ).

\section{Study Characteristics}

Table 4 illustrates the descriptive characteristics of the intrathecal infusion device studies evaluating non-cancer pain included in methodologic quality assessment.

In 1996, Winkelmüller \& Winkelmüller (71) evaluated the long-term effects of continuous intrathecal opioid treatment for chronic pain of nonmalignant etiology. Patients had neuropathic as well as nociceptive and mixed types of pain (majority of the patients - 73 of 120 , had pain arising from lumbar spinal surgeries). The follow-up period was from 6 months to 5.7 years, with only 36 patients followed up for $>4$ years. The deafferentation pain and neuropathic pain showed the best results on a long-term basis with $62 \%$ to $68 \%$ reduction in pain. Thirty-one or $25.8 \%$ of the 120 cases were considered treatment failures. Throughout the follow-up period, $74.2 \%$ of the patients benefited from the intrathecal opioid therapy, with an average pain reduction after 6 months of $67.4 \%$ and, as of the last follow-up examination, it was $58.1 \%$. Ninety-two percent of the patients were satisfied with the therapy and $81 \%$ reported an improvement in their QOL.

Although the authors describe a lengthy followup period ranging from 6 months to 5.7 years, it is not clear how many patients had been followed up for more than 12 months. The last follow-up period is mentioned in several of the parameters but is not clearly defined. Based on the review of the data, it appears that 36 patients received intrathecal opioid medications for a period of more than 4 years. Further, there were multiple complications with undesirable incidents and failures. They removed 25 pumps for various reasons. Twenty-six percent of the cases were considered as treatment failures. The overall success rate in 89 of the 120 patients benefiting from continuous opioid therapy over an observation period of 0.5 to 5.7 years is highly variable.

Roberts et al (72) collected data for intrathecal opioid administration in chronic non-cancer pain in 88 patients, out of which 67 had returned the questionnaires. The majority of the patients had failed lumbar spine surgery syndrome (63\%). Other indications for the implantable drug administration systems (DASs) included lumbar spine pain and radicular symptoms without surgery, cervical failed spine surgery, complex regional pain syndrome (CRPS), pancreatitis, and others. The authors focused on global pain relief, physical activity, work status, side effects, patients who ceased the therapy, and patient satisfaction. Although the observed patient satisfaction was high and the level of activity had increased, the return to work status did not change in the majority of the patients. The mean morphine does at 6-month follow-up was 9.95 $\mathrm{mg} /$ day, which increased to $15.26 \mathrm{mg} /$ day at 36-month follow-up, a relatively high dose. The patients had a long history of chronic pain with a mean duration of 9.8 years. Most patients had been receiving opioids and had been treated with various other modalities. The majority of the patients $(82 \%)$ reported pain relief greater than $50 \%$ and an increase in their activity levels. There was also a significant reduction in their oral medication intake, which would be expected given the high doses of intrathecal infusions. Reported side effects were excessive sweating, weight gain, difficulty with concentrating or memory, nausea/vomiting, arthralgia, peripheral edema, pruritus, sexual dysfunction, reduced libido, and menstrual abnormalities. Their reported difficulties with the system were high, and $40 \%$ of the patients required at least one surgical procedure to correct a technical problem. The authors concluded that there was improvement in analgesia with a reduction in medication intake, but it was offset by significantly increased intrathecal dosage. Also, the $40 \%$ device/catheter revision rate may not be ac- 
Intrethecal Infusion Systems for Chronic Non-Cancer Pain

Table 3. Methodologic quality assessment of observational studies evaluating non-cancer pain.

\begin{tabular}{|c|c|c|c|c|c|c|}
\hline CRITERION & $\begin{array}{c}\text { Weighted } \\
\text { Score } \\
\text { (points) }\end{array}$ & $\begin{array}{c}\text { Winkelmüller } \\
\text { \& } \\
\text { Winkelmüller } \\
1996 \text { (71) }\end{array}$ & $\begin{array}{c}\text { Rainov } \\
\text { et al } \\
2001 \\
(54)\end{array}$ & $\begin{array}{c}\text { Roberts } \\
\text { et al } \\
2001 \\
(72)\end{array}$ & $\begin{array}{c}\text { Deer et } \\
\text { al } \\
2002 \\
(73)\end{array}$ & $\begin{array}{c}\text { Thimineur } \\
\text { et al } \\
2004(74)\end{array}$ \\
\hline 1. Study Question & 2 & 2 & 2 & 2 & 2 & 2 \\
\hline - Clearly focused and appropriate question & & 2 & 2 & 2 & 2 & 2 \\
\hline 2. Study Population & 8 & 4 & 5 & 5 & 5 & 5 \\
\hline - Description of study population & 5 & 4 & 5 & 5 & 5 & 5 \\
\hline - Sample size justification & 3 & -- & -- & -- & -- & -- \\
\hline 3. Comparability of Subjects & 22 & 3 & 5 & 3 & 5 & 17 \\
\hline - Specific inclusion/exclusion criteria for all groups & 5 & 3 & 5 & 3 & 5 & 5 \\
\hline - Criteria applied equally to all groups & 3 & -- & -- & -- & -- & 3 \\
\hline $\begin{array}{l}\text { - Comparability of groups at baseline with regard to } \\
\text { disease status and prognostic factors }\end{array}$ & 3 & -- & -- & -- & -- & 3 \\
\hline $\begin{array}{l}\text { - Study groups comparable to non-participants with } \\
\text { regard to confounding factors }\end{array}$ & 3 & -- & -- & -- & -- & 3 \\
\hline - Use of concurrent controls & 5 & -- & -- & -- & -- & -- \\
\hline $\begin{array}{l}\text { - Comparability of follow-up among groups at each } \\
\text { assessment }\end{array}$ & 3 & -- & -- & -- & -- & 3 \\
\hline 4. Exposure or Intervention & 11 & 8 & 7 & 8 & 8 & 6 \\
\hline - Clear definition of exposure & 5 & 5 & 5 & 5 & 5 & 3 \\
\hline - Measurement method standard, valid and reliable & 3 & 3 & 2 & 3 & 3 & 3 \\
\hline - Exposure measured equally in all study groups & 3 & -- & -- & -- & -- & -- \\
\hline 5. Outcome measures & 20 & 14 & 12 & 12 & 13 & 13 \\
\hline - Primary/secondary outcomes clearly defined & 5 & 4 & 4 & 4 & 5 & 4 \\
\hline - Outcomes assessed blind to exposure or intervention & 5 & -- & - & -- & -- & -- \\
\hline $\begin{array}{l}\text { - Method of outcome assessment standard, valid and } \\
\text { reliable }\end{array}$ & 5 & 5 & 3 & 3 & 3 & 4 \\
\hline - Length of follow-up adequate for question & 5 & 5 & 5 & 5 & 5 & 5 \\
\hline 6. Statistical Analysis & 19 & 5 & 5 & 5 & 4 & 4 \\
\hline - Statistical tests appropriate & 5 & 5 & 5 & 5 & 4 & 4 \\
\hline - Multiple comparisons taken into consideration & 3 & -- & -- & -- & -- & -- \\
\hline - Modeling and multivariate techniques appropriate & 2 & -- & -- & -- & -- & -- \\
\hline - Power calculation provided & 2 & -- & -- & -- & -- & -- \\
\hline - Assessment of confounding & 5 & -- & -- & -- & -- & -- \\
\hline - Dose-response assessment if appropriate & 2 & -- & -- & -- & -- & -- \\
\hline 7. Results & 8 & 8 & 6 & 7 & 7 & 7 \\
\hline $\begin{array}{l}\text { - Measure of effect for outcomes and appropriate } \\
\text { measure of precision }\end{array}$ & 5 & 5 & 3 & 4 & 4 & 4 \\
\hline - Adequacy of follow-up for each study group & 3 & 3 & 3 & 3 & 3 & 3 \\
\hline 8. Discussion & 5 & 4 & 5 & 4 & 4 & 4 \\
\hline $\begin{array}{l}\text { - Conclusions supported by results with possible } \\
\text { biases and limitations taken into consideration }\end{array}$ & & 4 & 5 & 4 & 4 & 4 \\
\hline 9. Funding or Sponsorship & 5 & 5 & 2 & 4 & 5 & 2 \\
\hline - Type and sources of support for study & & 5 & 2 & 4 & 5 & 2 \\
\hline TOTAL SCORE & 100 & 53 & 49 & 50 & 53 & 60 \\
\hline
\end{tabular}

Adapted and modified from West S et al. Systems to Rate the Strength of Scientific Evidence, Evidence Report, Technology Assessment No. 47. AHRQ Publication No. 02-E016 (60). 
Table 4. Descriptive characteristics of the intrathecal infusion device studies evaluating non-cancer pain, meeting methodologic assessment criteria.

\begin{tabular}{|c|c|c|c|c|c|}
\hline $\begin{array}{l}\text { Study/ } \\
\text { Methods }\end{array}$ & Participants & Intervention(s) & Outcome(s) & Result(s) & Conclusion(s) \\
\hline $\begin{array}{l}\text { Winkelmüller } \\
\text { \& Winkel- } \\
\text { müller } \\
1996 \text { (71) }\end{array}$ & $\begin{array}{l}120 \text { patients with non- } \\
\text { cancer pain followed } \\
\text { from } 6 \text { mos. to } 5.7 \text { yrs. } \\
\text { Patients had nocicep- } \\
\text { tive-neuropathic pain } \\
\text { due to multiple lum- } \\
\text { bospinal operations. }\end{array}$ & $\begin{array}{l}\text { Intrathecal } \\
\text { morphine (+ } \\
\text { buprenorphine, } \\
\text { Clonidine, } \\
\text { fentanyl, or } \\
\mathrm{NaCl} \text { in various } \\
\text { combinations) } \\
\text { via implantable } \\
\text { pump. Addition- } \\
\text { al medications } \\
\text { were included as } \\
\text { a combination } \\
\text { and consisted } \\
\text { of bupivacaine, } \\
\text { Clonidine, } \\
\text { fentanyl, and } \\
\text { buprenorphine. }\end{array}$ & $\begin{array}{l}\text { Outcome measure- } \\
\text { ment with VAS } \\
\text { and McGill pain } \\
\text { questionnaire, level } \\
\text { of activity, mood, } \\
\text { QOL, complications } \\
\text { and side effects. }\end{array}$ & $\begin{array}{l}\text { Deafferentation pain and neuro- } \\
\text { pathic pain showed the best long-term } \\
\text { results, with } 68 \% \text { and } 62 \% \text { pain } \\
\text { reduction. Pain reduction after } 6 \\
\text { months was } 67.4 \% \text { and, as of the last } \\
\text { follow-up examination, it was } 58.1 \% \text {. } \\
92 \% \text { patients were satisfied with the } \\
\text { therapy and } 81 \% \text { reported an improve- } \\
\text { ment in their QOL. VAS measured } \\
\text { pre-implant }=93.6,6 \text { mo. Later VAS } \\
=30.5 \text {, Last f/u VAS = 39.2. Best initial } \\
\text { reduction in pain }(77 \%) \text { in nocicep- } \\
\text { tive group. Which decreased to } 48 \% \\
\text { at last f/u; improved level of activity; } \\
67 \% \text { pts. satisfied with pain level, } 81 \% \\
\text { improved QOL. Morphine was the } \\
\text { most effective and tolerated substance. } \\
\text { Complications: } 14 \text { pumps replaced, } 25 \\
\text { pumps removed (28.5\% pts considered } \\
\text { failures). }\end{array}$ & $\begin{array}{l}\text { Long-term admin- } \\
\text { istration of spinal } \\
\text { opioid medications } \\
\text { for nonmalignant } \\
\text { pain is encouraging } \\
\text { in carefully selected } \\
\text { patients. Good re- } \\
\text { sults were achieved } \\
\text { in a total of } 74.2 \% \\
\text { of the patients, and } \\
\text { a pain reduction of } \\
\text { approximately } 60 \% \\
\text { was reported even } \\
\text { after long-term } \\
\text { opioid application. }\end{array}$ \\
\hline $\begin{array}{l}\text { Roberts et al } \\
2001(72)\end{array}$ & $\begin{array}{l}88 \text { patients with } \\
\text { implanted drug adm. } \\
\text { systems }(1989-1996) \text {. } \\
\text { Diagnoses included } \\
\text { failed spinal surgery ( } \mathrm{n} \\
=55) \text {, lumbar spinal or } \\
\text { radicular pain without } \\
\text { surgery }(\mathrm{n}=6) \text {, CRPS } \\
\text { I (5), cervical failed } \\
\text { spinal surgery }(\mathrm{n}=4) \text {, } \\
\text { crush fractures }(\mathrm{n}=3) \text {, } \\
\text { chronic pancreatitis }(\mathrm{n} \\
=3 \text { ), others }(\mathrm{n}=12) .\end{array}$ & $\begin{array}{l}\text { Intrathecal opi- } \\
\text { oids (morphine) } \\
\text { via implantable } \\
\text { drug administra- } \\
\text { tions systems } \\
\text { after a successful } \\
\text { trial. }\end{array}$ & $\begin{array}{l}\text { Global pain relief, } \\
\text { physical activity } \\
\text { levels, medication } \\
\text { consumption, work } \\
\text { status, intrathecal } \\
\text { opioid side-effects, } \\
\text { proportion of } \\
\text { patients who ceased } \\
\text { therapy, and patient } \\
\text { satisfaction. }\end{array}$ & $\begin{array}{l}\text { Mean pain relief }-60 \% \text { with } 74 \% \\
\text { of patients ( } 36 \text { of } 49 \text { ) reporting } \\
\text { increased activity levels. Significant } \\
\text { reduction in oral medications. } \\
\text { Frequent side effects such as sexual } \\
\text { dysfunction, menstrual disturbance } \\
\text { were reported. } 88 \% \text { patients reported } \\
\text { high satisfaction levels. Change } \\
\text { in work status was not seen in the } \\
\text { patients. }\end{array}$ & $\begin{array}{l}\text { Intrathecal opioid } \\
\text { therapy appears to } \\
\text { have a place in the } \\
\text { management of } \\
\text { chronic non-cancer } \\
\text { pain. Therapy } \\
\text { does not seem to be } \\
\text { significantly inhib- } \\
\text { ited by the develop- } \\
\text { ment of tolerance. }\end{array}$ \\
\hline $\begin{array}{l}\text { Deer et al } \\
2002(73)\end{array}$ & $\begin{array}{l}109 \text { consecutive pa- } \\
\text { tients for bupivacaine } \\
+ \text { opioid compared } \\
\text { with opioid alone. } \\
84 \text { non-cancer } \\
\text { patients and } 25 \text { cancer } \\
\text { patients. }\end{array}$ & $\begin{array}{l}\text { Implantable } \\
\text { drug infusion } \\
\text { systems deliver- } \\
\text { ing opioid alone } \\
\text { vs opioid + } \\
\text { bupivacaine. }\end{array}$ & $\begin{array}{l}\text { Primary outcome } \\
\text { measure - pain } \\
\text { relief via VAS score, } \\
\text { secondary outcomes } \\
\text { amount of medica- } \\
\text { tions via other routes } \\
\text { (oral/transdermal), } \\
\text { ER visits, routine } \\
\text { office visits, patient } \\
\text { satisfaction. Neu- } \\
\text { rological complica- } \\
\text { tions reviewed with } \\
\text { combined drugs. }\end{array}$ & $\begin{array}{l}\text { With combination (bupivacaine + } \\
\text { opioid) infusion the pain relief was } \\
\text { significantly better, the number of } \\
\text { oral opioids used were significantly } \\
\text { less, number of oral nonopioid } \\
\text { adjuvants were reduced, number of } \\
\text { doctor's visits were less in the com- } \\
\text { bined arm, number of pain clinic } \\
\text { visits were less, the number of emer- } \\
\text { gency visits were significantly less } \\
\text { and patient satisfaction was better. } \\
\text { Total dose of morphine was reduced } \\
\text { by } 23 \% \text { with combined drugs. }\end{array}$ & $\begin{array}{l}\text { Bupivacaine, when } \\
\text { used in combina- } \\
\text { tion with opioids, } \\
\text { is a helpful and safe } \\
\text { method of } \\
\text { treatment in a } \\
\text { select population of } \\
\text { patients who have } \\
\text { not responded to } \\
\text { intrathecal opioids } \\
\text { alone }\end{array}$ \\
\hline $\begin{array}{l}\text { Thimineur } \\
\text { et al } \\
2004(74)\end{array}$ & $\begin{array}{l}69 \text { patients divided } \\
\text { into } 2 \text { groups. } 38 \text { pts. } \\
\text { received intrathecal } \\
\text { pump, } 31 \text { did not (pa- } \\
\text { tients with unsuccess- } \\
\text { ful trial or declined } \\
\text { intrathecal therapy). } \\
\text { Another group of new } \\
\text { patients ( } \mathrm{n}=41 \text { ) used } \\
\text { as comparative group. }\end{array}$ & $\begin{array}{l}\text { Intrathecal } \\
\text { morphine, } \\
\text { hydromorphone, } \\
\text { fentanyl, Cloni- } \\
\text { dine, Baclofen, } \\
\text { bupivacaine, and } \\
\text { methadone. Non } \\
\text { intrathecal group } \\
\text { continued the } \\
\text { pre-study medi- } \\
\text { cations (systemic } \\
\text { opioids). }\end{array}$ & $\begin{array}{l}\text { Multiple questionnaires } \\
\text { - symptom checklist } \\
90-\mathrm{R}, \text { SF36 Health } \\
\text { study, Beck depression } \\
\text { questionnaire, McGill } \\
\text { pain questionnaire } \\
\text { - short, Oswestry } \\
\text { disability index, Pain } \\
\text { drawing, VAS (1 - 10). } \\
\text { Evaluations done at base } \\
\text { line and then every } 6 \\
\text { months for } 3 \text { years. }\end{array}$ & $\begin{array}{l}\text { Intrathecal treatment had a signifi- } \\
\text { cant impact on pain, function, and } \\
\text { mood among study patients. Non- } \\
\text { recipients deteriorated despite esca- } \\
\text { lation of oral opioids and provision } \\
\text { of injection treatments. The base } \\
\text { line opioid requirements were higher } \\
\text { in the pump recipients (PR) than } \\
\text { non-recipients (NR). At } 36 \text { months, } \\
\text { the average daily oral morphine dose } \\
\text { had significantly decreased for PR } \\
\text { group and increased for NR. }\end{array}$ & $\begin{array}{l}\text { Intrathecal opioid } \\
\text { therapy for non- } \\
\text { cancer pain } \\
\text { should be consid- } \\
\text { ered appropriate } \\
\text { only when all other } \\
\text { conservative medi- } \\
\text { cal management has } \\
\text { been exhausted. }\end{array}$ \\
\hline
\end{tabular}


ceptable. Despite a significantly higher intrathecal dose, the authors claim that dose escalation did not appear to be a problem.

Deer et al (73) compared the effectiveness of a combination of bupivacaine with opioids and opioid alone. Their patient population included non-cancer as well as cancer pain (with spinal metastases), however the majority of patients had non-cancer pain (back and leg pain after unsuccessful back surgery). Patients served as their own comparison arm as they were on opioid alone prior to the inclusion of bupivacaine. Inclusion criteria were VAS more than 6 on at least 3 consecutive visits while on opioid alone. Consuming opioids via multiple routes was not an exclusion criterion. Patients with neurological complications while on opioid alone were excluded. Outcome data included pain levels, ER visits, patient satisfaction, regular clinic visits as well as medication intake via other routes. Mean exposure to bupivacaine was $62.2 \pm 21.3$ weeks for all patients, but the cancer patients' data obtained for a mean of only 28 weeks may have skewed this number. All but one patient experienced some reduction in pain as well as need for opioids via other routes. Use of non-opioid medications was also reduced but was statistically insignificant. No significant neurological sequelae from the use of bupivacaine were noted in the majority of patients. The authors concluded that in patients treated with intrathecal opioids, the addition of bupivacaine may improve outcomes. Side effects were rare and there was no evidence of neurological sequelae from the addition of bupivacaine to opioids via intrathecal infusion devices.

Thimineur et al (74) evaluated the long-term outcome of intrathecal opioid therapy in chronic noncancer pain prospectively and included 2 comparative groups to improve the understanding of the selection criteria and relative severity of intrathecal pump recipients. Data analysis suggests the study group of pump participants had improvements in pain, mood, and function from baseline to 36 months. However, the average reductions in pain in this study were less impressive than several previous investigations. The authors have not described the proportion of patients with significant pain relief of $50 \%$ or more. They concluded that intrathecal opioid therapy for non-cancer pain should be considered appropriate only when all other conservative medical management has been exhausted. Further confounding factors in this study included opioid medication administered to the recipients, along with injection treatments.
Of the studies not meeting inclusion criteria, Shaladi et al (75), in 2007, studied a group of older patients with severe osteoporosis and recent vertebral fracture. A clearly focused study evaluated the QOL in these patients with intrathecal morphine using a specific evaluation questionnaire for such populations with the Questionnaire of the European Foundation of Osteoporosis (QUALEFFO) on which a maximum score of 150 indicates poor health. This questionnaire evaluates QOL, domestic work, ambulation, and perception of health status, and was given to the patients after the implant as well as at oneyear follow-up. Patients were of an average age of 74.3 years and had a trial of conservative treatment for at least one-month with oral or transdermal opioids and still had a VAS of $\geq 7$. Also considered for implant were patients with severe side effects with systemic opioids such as vomiting, itching, constipation, or urinary retention, all resistant to pharmacologic therapy. There is mention of "drug addiction" as one of the inclusion criteria. Patients had $a \geq 50 \%$ improvement in pain after a trial of intrathecal morphine prior to the pump implant. Mean morphine dose, at trial, was $0.47 \mathrm{mg} / \mathrm{h}$, which corresponded to a mean VAS value of 3.7. The mean morphine dose used at pump implant was $0.33 \mathrm{mg} / \mathrm{h}$ and the mean morphine dose after one-year from the pump implantation was $0.68 \mathrm{mg} / \mathrm{h}$. The mean functional score QUALEFFO before trial was 114.7. After pump implant the mean QUALEFFO score had fallen to 92.1, and, after one-year, the mean QUALEFFO score fell to 79.1. Considering the pain from a recent vertebral fracture may normally improve after 6 months to a year, the contribution of the pump implant to the reduction in pain scores in this study is unclear. A comparative group of patients without intrathecal morphine would have clarified some questions as to the natural outcome of this pain type as well as the functional improvement of patients without any intrathecal morphine. With promising data on vertebroplasty as well as kyphoplasty, which are relatively cheaper options compared to an intrathecal infusion pump, and are also a one time treatment option, intrathecal morphine for vertebral fractures may have limited applications to patients who are not candidates for vertebral augmentation procedures. Other questions that remain unanswered are the long-term effects as well as side effects of such a high does of morphine (16.32 mg per day) after 2 years or more. 


\section{Effectiveness}

Table 5 illustrates results of the effectiveness of intrathecal infusion systems.

Of the 4 observational studies (71-74) meeting quality assessment criteria evaluating intrathecal infusion systems, 2 studies $(71,72)$ showed positive results for short- and long-term relief. The results were not available for one study (73) and were negative for one study (74).

\section{Level of Evidence}

The evidence for intrathecal infusion systems is either Level II-3 or Level III (limited) based on U.S. Preventive Services Task Force (USPSTF) criteria.

\section{Recommendation}

Based on Guyatt et al's criteria (70), the recommendation for intrathecal infusion systems is $1 \mathrm{C} /$ strong recommendation based on the current evidence derived from observational studies and the recommendation may change based on future evidence.

\section{Discussion}

The present systematic review with 5 observational studies meeting methodologic quality assessment (71-75) indicates that the evidence is Level II-3 or III (limited) based on USPSTF criteria with a recommendation of $1 \mathrm{C} /$ strong based on the evidence derived from observational studies. The evidence illustrated in this systematic review is similar to the previous systematic reviews, which also suffered from a paucity of evidence. It is rather surprising that despite multiple years of usage, numerous implants across the world, and significant arguments in favor of effectiveness, the available literature is so sparse.

This review focused on the use of intrathecal devices for intrathecal infusions of single as well a combination of drugs for chronic non-cancer pain only. Keeping the inclusion criteria stricter than some of the previous reviews helped filter the best evidence published to date for this modality. The definition of long-term relief as relief for longer than one year also provides robust criteria in the present systematic review.

Intrathecal infusion devices for chronic non-cancer pain have been utilized for the last quarter century. Although there was more focus on cancer pain earlier on, in the mid-nineties chronic non-cancer pain was also thought to be a major indication for intrathecal infusion of opioid medications. More combinations and substitutions were gradually introduced into practice over the course of several years. Although initial responses to this modality were very promising, drug tolerance as well as side effects gradually came into the picture and more and more complications began to be published. Cancer patients, having a more limited life span, did not provide the data on long-term chronic use of this modality.

Table 5. Results of published studies of effectiveness of intrathecal infusion systems.

\begin{tabular}{|c|c|c|c|c|c|c|c|}
\hline \multirow[b]{2}{*}{ Study } & \multirow[b]{2}{*}{$\begin{array}{c}\text { Study } \\
\text { Characteristics }\end{array}$} & \multirow[b]{2}{*}{$\begin{array}{l}\text { Methodological } \\
\text { Quality Scoring }\end{array}$} & \multirow[b]{2}{*}{ Participants } & \multicolumn{2}{|c|}{ Pain Relief } & \multicolumn{2}{|c|}{ Results } \\
\hline & & & & $\leq 12 \mathrm{mos}$ & $>12$ mos. & $\begin{array}{c}\text { Short-term } \\
\text { relief } \leq 12 \\
\text { months }\end{array}$ & $\begin{array}{c}\text { Long-term } \\
\text { relief }>12 \\
\text { months }\end{array}$ \\
\hline $\begin{array}{l}\text { Winkelmüller } \\
\text { \& Winkelmüller } \\
1996 \text { (71) }\end{array}$ & $\mathrm{O}$ & 53 & 120 & $74 \%$ & $74 \%$ & $\mathrm{P}$ & $\mathrm{P}$ \\
\hline $\begin{array}{l}\text { Roberts et al } 2001 \\
\text { (72) }\end{array}$ & $\mathrm{O}$ & 50 & 88 & $82 \%$ & $82 \%$ & $\mathrm{P}$ & $\mathrm{P}$ \\
\hline $\begin{array}{l}\text { Deer et al } 2002 \\
\text { (73) }\end{array}$ & $\mathrm{O}$ & 53 & 109 & NA & NA & NA & NA \\
\hline $\begin{array}{l}\text { Thimineur et al } \\
2004(74)\end{array}$ & $\mathrm{O}$ & 60 & $\begin{array}{c}38 \text { - pump } \\
31 \text { - non-pump }\end{array}$ & NA & $\mathrm{NA}$ & $\mathrm{N}$ & $\mathrm{N}$ \\
\hline $\begin{array}{l}\text { Shaladi et al } 2007 \\
\text { (75) }\end{array}$ & $\mathrm{O}$ & 55 & 24 & $100 \%$ & $100 \%$ & $\mathrm{P}$ & $\mathrm{P}$ \\
\hline
\end{tabular}

$\mathrm{O}=$ observational $\mathrm{P}=$ positive $\mathrm{N}=$ negative $\mathrm{NA}=$ not applicable 
A significant proportion of side effects and complications have been reported $(80,81)$. A $21.6 \%$ complication rate was shown in a retrospective analysis of 419 patients with at least 6 months of infusion time (81). In a small group of cancer patients the complication rate for infection, catheter failure, or pump failure was very limited (82). Technical complications include subdural intrathecal catheter placement (83), dural puncture and subdural injection (84), tension pseudomeningocele associated with retained intrathecal catheter (85), intrathecal granuloma formation $(86-88)$, peripheral edema $(89,90)$, and multiple treatment challenges and complications with ziconotide monotherapy in established pump patients (91). Further side effects include hormonal changes and respiratory depression. Several studies have reviewed intrathecal infusion devices in various forms. Most of them focused on a variety of indications (such as spasticity as well as cancer pain). The efficacy of intrathecal infusions may be better studied for separate indications as the follow-up times as well as the drugs contained in the infusion may have a significant impact on the outcomes of the study as well as the overall recommendations for this modality (92-94).

More recently, a focused review was published by Smith et al (95). The authors found that the evidence for implantable intrathecal infusion systems was strong for short-term improvement in pain of malignancy or neuropathic pain. The evidence was moderate for long-term management of persistent pain. Reasonably strong evidence exists for the use of long-term intrathecal analgesic therapy in the alleviation of cancer pain; however, the evidence supporting long-term efficacy in persistent non-cancer pain is less convincing. They concluded that the current body of literature supports the use of intrathecal agents for the treatment of moderate or severe pain related to cancer and non-cancer origins. However, the lack of systematic reviews of the published literature does not allow for proper grading of the quality of these studies. Combining various indications for this modality also prevents one from standardizing the recommendations.

One of the few prospective trials was published by Thimineur et al (74) in 2004. Two groups of patients were studied either with intrathecal infusion systems or without intrathecal infusion. Patients had chronic non-cancer pain. They also included a third group in the study for comparison. This group consisted of patients who were new recruits to the pain clinic. In this
3 year study, they evaluated several parameters at 6 month intervals. These parameters included Symptom Checklist-90 (SLC-90), SF-36 Health Survey (SF-36), Beck Depression Inventory, McGill Pain Questionnaire (short form) (SF-MPQ), Oswestry Disability Index (ODI), pain drawings, and pain rating on the visual analog scale (VAS). Their results indicated that the group that received intrathecal therapy had better pain control, mood, and function from the baseline data. The nonrecipients had significant worsening of their pain and function. However, even with the improved pain, mood, and function, the intrathecal group was still worse off than the new patient group at 36 months. This may be because of the long standing history of pain and dysfunction in the group that did receive intrathecal therapy. Interestingly, even the intrathecal group continued a high amount of opioids through other routes. Another fact is that the intrathecal infusions were not limited to opioids alone, which may have contributed to this apparent success.

Overall, the studies have shown a good longterm benefit from intrathecal infusion devices used for chronic non-cancer pain. Although the life span of patients should be considered several decades after pump implants, the studies seem to show a stable rate of analgesia at least for less than 10 years. This effect may not be as pronounced once the period is extended to more than a decade. Also, the formation of inflammatory masses in the form of granulomas is a major deterrent with this modality. As previously thought, the granuloma formation does not depend on the drug itself and has been seen with morphine as well as baclofen infusions. A Canadian study demonstrated the cost effectiveness of intrathecal infusion devices. Kumar et al (55) looked at the cost of implanting a programmable drug delivery pump vs. conservative treatment of chronic pain. Their patient population consisted of failed back syndrome. Successful outcomes were measured using the pain scale, ODI, and QOL. The cumulative costs for intrathecal drug delivery during a 5-year period were $\$ 29,410$, as opposed to $\$ 38,000$ for conservative treatments. High initial costs of equipment required for intrathecal drug delivery were recovered by 28 months. After this time, managing patients with conservative treatments became more expensive for the remainder of the followup period. The ODI showed a $27 \%$ improvement for patients in the intrathecal drug delivery group, compared with a $12 \%$ improvement in the control group. This is an important finding and may help justify the 
initial cost of the implantable pump system. However, considering the life of the programmable pump, there is obviously a high added cost for maintaining this treatment option beyond the initial life of the pump for the patient's life span.

The limitations of this systematic review includes the paucity of literature. There were no randomized trials available meeting the inclusion criteria. Further, observational studies are also very few. Systematic reviews in interventional pain management are signs of progress in the effort to keep pace with advances in health care innovations. Systematic reviews have been growing at a rapid pace in interventional pain management $(96,97)$. Systematic reviews are at the core of evidence-based medicine which is a shift in medical paradigms that acknowledges that intuition, unsystematic clinical experience, and pathophysiologic rationale are insufficient grounds for clinical decisionmaking (98-100). In the hierarchy of strength of evidence for treatment decisions, $\mathrm{N}$ of $1 \mathrm{RCT}$ occupies the top place, followed by systematic reviews of randomized trials, systematic reviews of observational studies, followed by unsystematic clinical observations. Thus, observational studies and their systematic reviews are lower in the hierarchy than the randomized trials and their systematic reviews. Randomized trials provide valuable evidence about treatments and other interventions. However, most of the research in clinical practice comes from observational studies (101-103). Randomized trials work by first assuming there is no difference between a new and an old or placebo treatment to prove the null hypothesis (104). In simplistic terms, standard RCTs are designed to show that treatments do not work, rather than to demonstrate that treatments do work. Numerous criticisms, politics, and a lack of understanding of randomized trials have resulted in allegations that the research performed to test new treatments has often been of poor quality. Thus, clinicians have criticized the research establishment for failing to provide answers to relevant clinical problems of everyday practice $(105,106)$. Most questions in medical research are investigated by observational studies $(1,28,31,32,36-42,107-115)$ which are more likely to provide an indication of daily medical practices (116). Thus, proponents of observational studies believe that observational studies are just as effective as RCTs. However, from a methodologic perspective, the 2 types of studies are considered complementary rather than opposing (109). Thus, observa- tional studies and RCTs can be viewed as expressions in the setting of modern clinical research of the steps of observation and experimentation that form the basis of scientific methodology. The observational step is used to uncover patterns and formulate hypothesis regarding cause-and-effect relationships, which is followed by the experimentation step in which the hypotheses formed in the observational setting are confirmed or refuted in an experiment in which the independent variables are controlled by the experimenter $(109,117,118)$. A major drawback of observational research is of poor reporting as it results in an inability to assess the strengths and weaknesses of the investigations $(102,103,117,118)$. These deficiencies can be overcome by an assessment of the methodologic quality of observational studies. There are several instruments for methodologic quality assessment of randomized trials (100). In this systematic review, we have utilized West et al's (60) described criteria from the AHRQ evidence report of technology assessment. They assessed 19 systems relating to observational studies or investigations prior to developing the criteria. Consequently, we believe that this systematic review provides appropriate information.

The major argument made by researchers is that interventions such as intrathecal implantables may not be performed in a double blind manner. However, they can be performed as equivalence or non-inferiority trials with randomization, but without blinding. In fact, multiple studies describing interventions have been performed in this manner (27-38,61-68,119-123).

\section{Conclusion}

Intrathecal infusion devices used for the treatment of chronic intractable pain provide positive long-term outcomes and may have a role as an advanced-stage therapy for refractory pain.

This systematic review illustrates Level II-3 or Level III (limited) evidence for intrathecal infusion systems for long-term relief in chronic non-cancer pain.

\section{Acknowledgments}

The authors wish to thank the editorial board of Pain Physician, for review and criticism in improving the manuscript; Vidyasagar Pampati, MSc, statistician; Sekar Edem for assistance in search of literature; and Tonie M. Hatton and Diane E. Neihoff, transcriptionists (Pain Management Center of Paducah), for their assistance in the preparation of this manuscript. 


\section{References}

1. Boswell MV, Trescot AM, Datta S, Schultz DM, Hansen HC, Abdi S, Sehgal N, Shah RV, Singh V, Benyamin RM, Patel VB, Buenaventura RM, Colson JD, Cordner HJ, Epter RS, Jasper JF, Dunbar EE, Atluri SL, Bowman RC, Deer TR, Swicegood JR, Staats PS, Smith HS, Burton AW, Kloth DS, Giordano J, Manchikanti L. Interventional techniques: Evidencebased practice guidelines in the management of chronic spinal pain. Pain Physician 2007; 10:7-111.

2. Freburger JK, Holmes GM, Agans RP, Jackman AM, Darter JD, Wallace AS, Castel LD, Kalsbeek WD, Carey TS. The rising prevalence of chronic low back pain. Arch Intern Med 2009; 169:251258.

3. Luo X, Pietrobon R, Sun SX, Liu GG, Hey L. Estimates and patterns of direct health care expenditures among individuals with back pain in the United States. Spine 2004; 29:79-86.

4. Bell G, Kidd D, North R. Cost-effectiveness analysis of spinal cord stimulation in treatment of failed back surgery syndrome. J Pain Symp Manage 1997; 13:286-295.

5. de Lissovoy G, Brown RE, Halpern M, Hassenbusch SJ, Ross E. Cost-effectiveness of long-term intrathecal morphine therapy for pain associated with failed back surgery syndrome. Clin Ther 1997; 19:96-112.

6. Ricci JA, Stewart WF, Chee E, Leotta C, Foley K, Hochberg MC. Back pain exacerbations and lost productive time costs in United States workers. Spine 2006; 31:3052-3060.

7. Leigh JP, Markowitz SB, Fahs M, Shin C, Landrigan PJ. Occupational injury and illness in the United States. Estimates of costs, morbidity, and mortality. Arch Intern Med 1997; 157:1557-1568.

8. Asche CV, Kirkness CS, McAdam-Marx C, Fritz JM. The societal costs of low back pain: Data published between 2001 and 2007. J Pain Palliat Care Pharmacother 2007; 21:25-33.

9. Deyo RA, Mirza SK, Turner JA, Martin BI. Overtreating chronic back pain: Time to back off? J Am Board Fam Med 2009; 22:62-68.

10. Harkness EF, Macfarlane GJ, Silman AJ, McBeth J. Is musculoskeletal pain more common now than 40 years ago?: Two population-based cross-sectional studies. Rheumatology (Oxford) 2005; 44:890-895.
11. The High Price of Pain: The Economic Impact of Persistent Pain in Australia. Report prepared by Access Economics Pty Limited for the MBF Foundation in collaboration with the University of Sydney Pain Management Research Institute. November 2007.

12. Berger A, Dukes EM, Oster G. Clinical characteristics and economic costs of patients with painful neuropathic disorders. J Pain 2004; 5:143-149.

13. Rodriguez MJ, Garcia AJ; Investigators of Collaborative Study REC. A registry of the aetiology and costs of neuropathic pain in pain clinics: Results of the registry of aetiologies and costs (REC) in neuropathic pain disorders study. Clin Drug Investig 2007; 27:771-782.

14. Goetzel RZ, Hawkins K, Ozminkowski RJ, Wang S. The health and productivity cost burden of the "top 10" physical and mental health conditions affecting six large U.S. employers in 1999. I Occup Environ Med 2003; 45:5-14.

15. Stewart WF, Ricci JA, Chee E, Morganstein D, Lipton R. Lost productive time and cost due to common pain conditions in the US workforce. JAMA 2003; 290:2443-2454.

16. Martin BI, Deyo RA, Mirza SK, Turner JA, Comstock BA, Hollingworth W, Sullivan SD. Expenditures and health status among adults with back and neck problems. JAMA 2008; 299:656-664.

17. Schofferman J, Reynolds J, Herzog R, Covington E, Dreyfuss P, O'Neill C. Failed back surgery: Etiology and diagnostic evaluation. Spine J 2003; 3:400403.

18. Slipman $\mathrm{CW}$, Shin $\mathrm{CH}$, Patel RK, Isaac Z, Huston CW, Lipetz JS, Lenrow DA, Braverman DL, Vresilovic EJ Jr. Etiologies of failed back surgery syndrome. Pain Med 2002; 3:200-214.

19. Waguespack A, Schofferman J, Slosar P, Reynolds J. Etiology of long-term failures of lumbar spine surgery. Pain Med 2002; 3:18-22.

20. Waddell G, Kummel EG, Lotto WN, Graham JD, Hall H, McCulloch JA. Failed lumbar disc surgery and repeat surgery following industrial injury. J Bone Joint Surg Am 1979; 61:201-207.

21. Lieberman IH. Disc bulge bubble: Spine economics 101. Spine / 2004; 4:609613.

22. Eisner W. Spinal fusion: CMS says "show us the evidence in November."
Orthopedics This Week, July 26, 2006; www.ryortho.com/newsletters/volume2/issue24/07-25-06

23. Deyo RA, Nachemson A, Mirza SK. Spinal fusion surgery - The case for restraint. N Engl J Med 2004; 350:722726.

24. Deyo RA, Mirza SK. Trends and variations in the use of spine surgery. Clin Orthop Relat Res 2006; 443:139-146.

25. McCrory DC, Turner DA, Patwardhan MB, Richardson WL. DRAFT Spinal Fusion for Degenerative Disc Disease Affecting the Lumbar Spine. Agency for Healthcare Research and Quality. Duke Evidence-Based Practice Center. November 1, 2006. www.cms.hhs.gov/determinationprocess/downloads/id41ta. pdf

26. Brox JI, Sørensen R, Friis A, Nygaard Ø, Indahl A, Keller A, Ingebrigtsen T, Eriksen HR, Holm I, Koller AK, Riise R, Reikerås $\mathrm{O}$. Randomized clinical trial of lumbar instrumented fusion and cognitive intervention and exercises in patients with chronic low back pain and disc degeneration. Spine 2003; 28:1913-1921.

27. Heavner JE, Racz GB, Raj P. Percutaneous epidural neuroplasty. Prospective evaluation of $0.9 \% \mathrm{NaCl}$ versus $10 \%$ $\mathrm{NaCl}$ with or without hyaluronidase. Reg Anesth Pain Med 1999; 24:202207.

28. Conn A, Buenaventura RM, Datta S, Abdi S, Diwan S. Systematic review of caudal epidural injections in the management of chronic low back pain. Pain Physician 2009; 12:109-135.

29. Manchikanti L, Singh V, Cash KA, Pampati V, Datta S. Preliminary results of randomized, equivalence trial of fluoroscopic caudal epidural injections in managing chronic low back pain: Part 3. Post surgery syndrome. Pain Physician 2008; 11:817-831.

30. Manchikanti L, Cash KA, McManus CD, Pampati V, Abdi S. Preliminary results of randomized, equivalence trial of fluoroscopic caudal epidural injections in managing chronic low back pain: Part 4. Spinal stenosis. Pain Physician 2008; 11:833-848.

31. Abdi S, Datta S, Trescot AM, Schultz DM, Adlaka R, Atluri SL, Smith HS, Manchikanti L. Epidural steroids in the management of chronic spinal pain: A systematic review. Pain Physician 2007; 10:185-212. 
32. Trescot AM, Chopra P, Abdi S, Datta S, Schultz DM. Systematic review of effectiveness and complications of adhesiolysis in the management of chronic spinal pain: An update. Pain Physician 2007; 10:129-146.

33. Manchikanti L, Boswell MV, Rivera JJ, Pampati V, Damron KS, McManus CD, Brandon DE, Wilson SR. A randomized, controlled trial of spinal endoscopic adhesiolysis in chronic refractory low back and lower extremity pain. $B M C$ Anesthesiol 2005; 5:10.

34. Manchikanti L, Rivera JJ, Pampati V, Damron KS, McManus CD, Brandon DE, Wilson SR. One day lumbar epidural adhesiolysis and hypertonic saline neurolysis in treatment of chronic low back pain: A randomized, double-blind trial. Pain Physician 2004; 7:177-186.

35. Manchikanti L, Rivera JJ, Pampati V, Damron KS, Beyer CD, Brandon DE, Wilson SR. Spinal endoscopic adhesiolysis in the management of chronic low back pain: A preliminary report of a randomized, double-blind trial. Pain Physician 2003; 6:259-267.

36. Epter RS, Helm S, Hayek SM, Benyamin RM, Smith HS, Abdi S. Systematic Re view of Percutaneous Adhesiolysis and Management of Chronic Low Back Pain in Post Lumbar Surgery Syndrome. Pain Physician 2009; 12:361-378.

37. Manchikanti L, Saini B, Singh V. Spinal endoscopy and lysis of epidural adhesions in the management of chronic low back pain. Pain Physician 2001; 4:240-265.

38. Hayek SM, Helm S, Benyamin RM, Singh V, Bryce DA, Smith HS. Effectiveness of Spinal Endoscopic Adhesiolysis in Post Lumbar Surgery Syndrome: A Systematic Review. Pain Physician 2009; 12:419-435.

39. Manchikanti L, Hirsch JA. Issues in health care: Interventional pain management at the crossroads. Health policy update. Pain Physician 2007; 10:261-284.

40. Manchikanti L, Boswell MV. Interventional techniques in ambulatory surgical centers: A look at the new payment system. Pain Physician 2007; 10:627650.

41. Manchikanti L, Giordano J. Physician payment 2008 for interventionalists: Current state of health care policy. Pain Physician 2007; 10:607-626.

42. Manchikanti L, Singh V, Pampati V, Smith HS, Hirsch J. Analysis of growth in interventional techniques in managing chronic pain in Medicare population: A 10-year evaluation from 1997 to 2006. Pain Physician 2009; 12:9-34.

43. Specialty Utilization data files from CMS: www.cms.hhs.gov

44. American College of Occupational and Environmental Medicine (ACOEM). Low Back Disorders Chapter. In: Occupa tional Medicine Practice Guidelines: Evaluation and Management of Com mon Health Problems and Functional Recovery of Workers, Second Edition. American College of Occupational and Environmental Medicine, Elk Grove Village, 2007.

45. American College of Occupational and Environmental Medicine (ACOEM). Chronic Pain Chapter (revised 2008). In: Occupational Medicine Practice Guidelines: Evaluation and Management of Common Health Problems and Functional Recovery of Workers, Second Edition. American College of Occupational and Environmental Medicine, Elk Grove Village, Epublished August 14, 2008.

46. Manchikanti L, Singh V, Derby R, Helm $S$, Trescot AM, Staats PS, Prager JP, Hirsch JA. Review of occupational medicine practice guidelines for interventional pain management and potential implications. Pain Physician 2008; 11:271-289.

47. Manchikanti L, Singh V, Helm S, Trescot AM, Hirsch JA. A critical appraisal of 2007 American College of Occupational and Environmental Medicine (ACOEM) practice guidelines for interventional pain management: An independent review utilizing AGREE, AMA, IOM, and other criteria. Pain Physician 2008; 11:291-310.

48. Manchikanti L, Singh V, Derby R, Schultz DM, Benyamin RM, Prager JP, Hirsch JA. Reassessment of evidence synthesis of occupational medicine practice guidelines for interventional pain management. Pain Physician 2008; 11:393482.

49. Bennett G, Burchiel K, Buchser E, Classen A, Deer T, Du Pen S, Ferrante FM, Hassenbusch SJ, Lou L, Maeyaert J, Penn R, Portenoy RK, Rauck R, Serafini M, Willis KD, Yaksh T. Clinical guidelines for intraspinal infusion: Report of an expert panel. J Pain Symptom Manage 2000; 20:S37-S43.

50. Walker SM, Goudas LC, Cousins MJ, Carr DB. Combination spinal analgesic chemotherapy: A systematic review. Anesth Analg 2002; 95:674-715.

51. Turner JA, Sears JM, Loeser JD. Programmable intrathecal opioid delivery systems for chronic non-malignant pain: A systematic review of effectiveness and complications. Clin J Pain 2007; 23:180-195.

52. Anderson VC, Burchiel KJ. A prospective study of long-term intrathecal morphine in the management of chronic nonmalignant pain. Neurosurgery 1999; 44:289-300.

53. Kumar K, Kelly M, Pirlot T. Continuous intrathecal morphine treatment for chronic pain of nonmalignant etiology: Long-term benefits and efficacy. Surg Neurol 2001; 55:79-88.

54. Rainov NG, Heidecke V, Burkert W. Long-term intrathecal infusion of drug combinations for chronic back and leg pain. J Pain Symptom Manage 2001; 22:862-871.

55. Kumar K, Hunter G, Demeria DD. Treatment of chronic pain by using intrathecal drug therapy compared with conventional pain therapies: A cost effectiveness analysis. J Neurosurg 2002; 97:803-810.

56. Anderson VC, Burchiel KJ, Cooke B. A prospective, randomized trial of intrathecal injection vs. epidural infusion in the selection of patients for continuous intrathecal opioid therapy. Neuromodulation 2003; 6:142-152.

57. Deer T, Chapple I, Classen A, Javery K, Stoker V, Tonder L, Burchiel K. Intrathecal drug delivery for treatment of chronic low back pain: Report from the National Outcomes Registry for Low Back Pain. Pain Med 2004; 5:6-13.

58. Mueller-Schwefe G, Hassenbusch SJ, Reig E. Cost-effectiveness of intrathecal therapy for pain. Neuromodulation 1999; 2:77-84.

59. Koes BW, Scholten RJ, Mens JM, Bouter LM. Efficacy of epidural steroid injections for low-back pain and sciatica: A systematic review of randomized clinical trials. Pain 1995; 63:279-288.

6o. West S, King V, Carey TS, Lohr KN, McKoy N, Sutton SF, Lux L. Systems to Rate the Strength of Scientific Evidence, Evidence Report, Technology Assessment No. 47. AHRQ Publication No. 02E016. Rockville, MD: Agency for Healthcare Research and Quality, 2002. www. thecre.com/pdf/ahrq-system-strength. pdf 
61. Atluri S, Datta S, Falco FJ, Lee M. Systematic review of diagnostic utility and therapeutic effectiveness of thoracic facet joint interventions. Pain Physician 2008; 11:611-629.

62. Datta S, Lee M, Falco FJE, Bryce DA, Hayek SM. Systematic Assessment of Diagnostic Accuracy and Therapeutic Utility of Lumbar Facet Joint Interventions. Pain Physician 2009; 12:437460.

63. Falco FJE, Erhart S, Wargo BW, Bryce DA, Atluri S, Datta S, Hayek SM. Systematic Review of Diagnostic Utility and Therapeutic Effectiveness of Cervical Facet Joint Interventions. Pain Physician 2009; 12:323-344.

64. Frey ME, Manchikanti L, Benyamin RM, Schultz DM, Smith HS, Cohen SP. Spinal Cord Stimulation for Patients with Failed Back Surgery Syndrome: A Systematic Review. Pain Physician 2009; 12:379-397.

65. Manchikanti L, Dunbar EE, Wargo BW, Shah RV, Derby R, Cohen SP. Systematic Review of Cervical Discography as a Diagnostic Test for Chronic Spinal Pain. Pain Physician 2009; 12:305-321.

66. Buenaventura RM, Datta S, Abdi S, Smith HS. Systematic review of therapeutic lumbar transforaminal epidural steroid injections. Pain Physician 2009; 12:233-251.

67. Benyamin RM, Singh V, Parr AT, Conn A, Diwan S, Abdi S. Systematic review of the effectiveness of cervical epidurals in the management of chronic neck pain. Pain Physician 2009; 12:137-157.

68. Rupert MP, Lee M, Manchikanti L, Datta S, Cohen SP. Evaluation of Sacroiliac Joint Interventions: A Systematic Appraisal of the Literature. Pain Physician 2009; 12:399-418.

69. Berg AO, Allan JD. Introducing the third U.S. Preventive Services Task Force. Am J Prev Med 2001; 20:S3-S4.

70 Guyatt G, Gutterman D, Baumann MH, Addrizzo-Harris D, Hylek EM, Phillips B, Raskob G, Lewis SZ, Schünemann $H$. Grading strength of recommendations and quality of evidence in clinical guidelines. Report from an American College of Chest Physicians Task Force. Chest 2006; 129:174-181.

71. Winkelmüller $M$, Winkelmüller W. Longterm effects of continuous intrathecal opioid treatment in chronic pain of nonmalignant etiology. I Neurosurg 1996; 85:458-467.

72. Roberts LJ, Finch PM, Goucke CR, Price
LM. Outcome of intrathecal opioids in chronic non-cancer pain. Eur J Pain 2001; 5:353-361.

73. Deer TR, Caraway DL, Kim CK, Dempsey $C D$, Stewart CD, McNeil KF. Clinical experience with intrathecal bupivacaine in combination with opioid for the treatment of chronic pain related to failed back surgery syndrome and metastatic cancer pain of the spine. Spine J 2002; 2:274-278.

74. Thimineur MA, Kravitz E, Vodapally MS Intrathecal opioid treatment for chronic non-malignant pain: A 3 year prospective study. Pain 2004; 109:242-249.

75. Shaladi A, Saltari MR, Piva B, Crestani F, Tartari S, Pinato P, Michelleto G, Dall'Ara R. Continuous intrathecal morphine infusion in patients with vertebral fractures due to osteoporosis. Clin J Pain 2007; 23:511-517.

76. Wulf $\mathrm{H}$, Gleim M, Mignat C. The stability of mixtures of morphine hydrochloride, bupivacaine hydrochloride, and clonidine hydrochloride in portable pump reservoirs for the management of chronic pain syndromes. J Pain Symptom Manage 1994; 9:308-311.

77. Krames ES, Lanning RM. Intrathecal infusional analgesia for nonmalignant pain: Analgesic efficacy of intrathecal opioid with or without bupivacaine. J Pain Symptom Manage 1993; 8:539548.

78. Lynch SS, Cheng CM, Yee JL. Intrathecal ziconotide for refractory chronic pain. Ann Pharmacother 2006; 40:12931300.

79. Staats PS, Yearwood T, Charapata SG, Presley RW, Wallace MS, Byas-Smith $M$, Fisher R, Bryce DA, Mangieri EA, Luther RR, Mayo M, McGuire D, Ellis D. Intrathecal ziconotide in the treatment of refractory pain in patients with cancer or AIDS: A randomized controlled trial. JAMA 2004; 291:63-70.

80. Deer TR. Intrathecal drug delivery systems. In: Manchikanti L, Singh V (eds.) Interventional Techniques in Chronic Spinal Pain. ASIPP Publishing, Paducah, KY, 2007, pp 665-680.

81. Paice, J, Penn R, Shott S. Intraspinal morphine for chronic pain: A retrospective, multicenter study. J Pain Symptom Manage 1996; 11:71-80.

82. Coombs D, Maurer L, Saunders R, Gaylor M. Outcomes and complications of continuous intraspinal narcotic analgesia for cancer pain control. J Clin Oncol 1984; 2:1414-1420.
83. Sorokin A, Annabi E, Yang WC, Kaplan R. Subdural intrathecal catheter placement: Experience with two cases. Pain Physician 2008; 11:677-680.

84. Goodman BS, Bayazitoglu M, Mallempati S, Noble BR, Geffen JF. Dural puncture and subdural injection: A complication of lumbar transforaminal epidural injections. Pain Physician 2007; 10:697-705.

85. Vodapally MS, Thimineur MA, Mastroianni PP. Tension pseudomeningocele associated with retained intrathecal catheter: A case report with a review of literature. Pain Physician 2008; 11:355362.

86. Deer TR. A prospective analysis of intrathecal granuloma in chronic pain patients: A review of the literature and report of a surveillance study. Pain Physician 2004; 7:225-228.

87. Ramsey CN, Owen RD, Witt WO, Grider JS. Intrathecal granuloma in a patient receiving high dose hydromorphone. Pain Physician 2008; 11:369-373.

88. Ruan X, Tadia R, Couch JP, Ruan J, Chiravuri $S$. Severe peripheral edema during an outpatient continuous epidural morphine infusion trial in a patient with failed back surgery syndrome. Pain Physician 2008; 11:363-367.

89. Raj PP, Shah RV, Kaye AD, Denaro S, Hoover JM. Bleeding risk in interventional pain practice: assessment, management, and review of the literature. Pain Physician 2004; 7:3-51.

90. Thompson JC, Dunbar E, Laye RR. Treatment challenges and complications with ziconotide monotherapy in established pump patients. Pain Physician 2006; 9:147-152.

91. Ghafoor VL, Epshteyn M, Carlson GH, Terhaar DM, Charry O, Phelps PK. Intrathecal drug therapy for long-term pain management. Am J Health Syst Pharm 2007; 64:2447-2461.

92. Dones I. Intrathecal Baclofen for the treatment of spasticity. Acta Neurochir Suppl 2007; 97:185-188.

93. Sloan PA. Neuraxial pain relief for intractable cancer pain. Curr Pain Headache Rep 2007; 11:283-289.

94. Knight KH, Brand FM, Mchaourab AS, Veneziano G. Implantable intrathecal pumps for chronic pain: Highlights and updates. Croat Med J 2007; 48:22-34.

95. Smith HS, Deer TR, Staats PS, Singh V, Sehgal N, Cordner H. Intrathecal drug delivery. Pain Physician 2008; 11:S89S104. 
96. Manchikanti L, Boswell MV, Giordano J. Evidence-based interventional pain management: Principles, problems, potential, and applications. Pain Physician 2007; 10:329-356.

97. Manchikanti L. Evidence-based medicine, systematic reviews, and guidelines in interventional pain management: Part 1: Introduction and general considerations. Pain Physician 2008; 11:161-186

98. Manchikanti L, Hirsch JA, Smith HS. Evidence-based medicine, systematic reviews, and guidelines in interventional pain management: Part 2: Randomized controlled trials. Pain Physician 2008; 11:717-773.

99. Manchikanti L, Benyamin RM, Helm S, Hirsch JA. Evidence-based medicine, systematic reviews, and guidelines in interventional pain management: Part 3: Systematic reviews and meta-analysis of randomized trials. Pain Physician 2009; 12:35-72.

100. Manchikanti L, Singh V, Smith HS, Hirsch JA. Evidence-based medicine, systematic reviews, and guidelines in interventional pain management: Part 4: Observational studies. Pain Physician 2009; 12:73-108.

101. Guyatt G, Drummond R. Part 1. The basics: Using the medical literature. $1 \mathrm{~A}$. Introduction: The philosophy of evidence-based medicine. In: Guyatt G, Rennie D (eds). Users' Guides to the Medical Literature: A Manual for EVidence-Based Clinical Practice. AMA Press, Chicago, 2002, pp 3-12.

102. Vandenbroucke JP, von Elm E, Altman DG, Gøtzsche PC, Mulrow CD, Pocock SJ, Poole C, Schlesselman JJ, Egger M, STROBE Initiative. Strengthening the Reporting of Observational Studies in Epidemiology (STROBE): Explanation and elaboration. Ann Intern Med 2007; 147:W163-W194.

103. von Elm E, Altman DG, Egger M, Pocock SJ, Gøtzsche PC, Vandenbroucke JP, STROBE Initiative. The Strengthening the Reporting of Observational Studies in Epidemiology (STROBE) Statement: Guidelines for reporting observational studies. Ann Intern Med 2007;
147:573-577.

104. Healy D. Randomized Controlled Trials: Evidence Biased Psychiatry. Alliance for Human Research Protection, 2002. www.ahrp.org/COI/healyo802.php

105. Miles A, Charlton B, Bentley P, Polychronis A, Grey J, Price N. New perspectives in the evidence-based healthcare debate. J Eval Clin Pract 2000; 6:77-84.

106. Glasziou P, Vandenbroucke JP, Chalm ers I. Assessing the quality of research. BMJ 2004; 328:39-41.

107. Black N. Why we need observational studies to evaluate the effectiveness of health care. BMJ 1996; 312:1215-1218.

108. Scales CD Jr., Norris RD, Peterson BL, Preminger GM, Dahm P. Clinical research and statistical methods in the urology literature. J Urol 2005; 174:1374-1379.

109. Greene T. Are observational studies "just as effective" as randomized clinical trials? Blood Purif 2000; 18:317322

110. Boswell MV, Colson JD, Sehgal N, Dunbar EE, Epter R. A systematic review of therapeutic facet joint interventions in chronic spinal pain. Pain Physician 2007; 10:229-253.

111. Hansen HC, McKenzie-Brown AM, Cohen SP, Swicegood JR, Colson JD, Manchikanti L. Sacroiliac joint interventions: A systematic review. Pain Physician 2007; 10:165-184.

112. Manchikanti L, Singh V, Vilims BD, Hansen HC, Schultz DM, Kloth DS. Medial branch neurotomy in management of chronic spinal pain: Systematic review of the evidence. Pain Physician 2002; 5:405-418.

113. Dreyfuss P, Halbrook B, Pauza K, Joshi A, McLarty J, Bogduk N. Efficacy and validity of radiofrequency neurotomy for chronic lumbar zygapophysial joint pain. Spine 2000; 25:1270-1277.

114. Sehgal N, Shah RV, McKenzie-Brown A, Everett CR. Diagnostic utility of facet (zygapophysial) joint injections in chronic spinal pain: A systematic review of evidence. Pain Physician 2005; 8:211-224.

115. Singh V, Manchikanti L, Shah RV, Dun- bar EE, Glaser SE. Systematic review of thoracic discography as a diagnostic test for chronic spinal pain. Pain Physician 2008; 11:631-642.

116. Papanikolaou PN, Christidi GD, Ioannidis JP. Comparison of evidence on harms of medical interventions in randomized and nonrandomized studies. CMAJ 2006; 174:635-641.

117. Hempel CG. Philosophy of Natural Science. Prentice-Hall, Englewood Cliffs, 1966.

118. Popper KR. The Logic of Scientific Discovery. Cambridge University Press, London, 1958.

119. Manchikanti L, Cash KA, McManus CD, Pampati V, Smith HS. Preliminary results of randomized, equivalence trial of fluoroscopic caudal epidural injections in managing chronic low back pain: Part 1. Discogenic pain without disc herniation or radiculitis. Pain Physician 2008; 11:785-800.

120. Manchikanti L, Singh V, Cash KA, Pampati V, Damron KS, Boswell MV. Preliminary results of randomized, equivalence trial of fluoroscopic caudal epidural injections in managing chronic low back pain: Part 2. Disc herniation and radiculitis. Pain Physician 2008; 11:801-815.

121. Manchikanti L, Singh V, Falco FJE, Cash KA, Pampati V. Effectiveness of thoracic medial branch blocks in managing chronic pain: A preliminary report of a randomized, double-blind controlled trial; Clinical trial NCTo0355706. Pain Physician 2008; 11:491-504.

122. Manchikanti L, Singh V, Falco FJ, Cash KA, Fellows B. Cervical medial branch blocks for chronic cervical facet joint pain: A randomized double-blind, controlled trial with one-year follow-up. Spine 2008; 33:1813-1820.

123. Manchikanti L, Singh V, Falco FJ, Cash KA, Pampati V. Lumbar facet joint nerve blocks in managing chronic facet joint pain: One-year follow-up of a randomized, double-blind controlled trial: Clinical Trial NCTo0355914. Pain Physician 2008; 11:121-132. 